\title{
AKTIVITAS PEMASARAN PRODUK SIMPANAN PT. BANK TABUNGAN NEGARA (PERSERO)TbK KANTOR CABANG PADANG
}

\author{
Rizki Amelia, Ratna Widayati \\ Akademi Keuangan dan Perbankan Padang \\ ratnawidayati@akbpstie.ac.id
}

\begin{abstract}
The development in the banking industry as well as opening the era of free information has contributed to greater competition between banks. Competition led to similar companies competing to create a strategy to win the competition, one of which is the marketing strategy. PT. Bank Tabungan Negara (Persero) Tbk. Padang Branch Office conduct marketing activities of deposit products using the marketing mix strategy into the programs created. In the banking service products are components of the marketing mix, namely Product, Price, Place, and Promotion, which is in development now, has undergone additions into: People, Process, and Phisical Evidence. Seven of the marketing mix is able to support customers' purchasing decisions. It is seen from the achievement of the target product, namely fund raising savings, deposits, and current accounts.
\end{abstract}

Keywords : Activities Marketing and Marketing Strategy

PENDAHULUAN

Persaingan perbankan dan situasi bisnis di pasar saat ini berubah dengan sangat cepat. Kondisi tersebut berhadapan pula dengan sistem pasar global dengan tingkat persaingan yang semakin tajam di pasar domestik maupun pasar Internasional. Masingmasing bank berlomba untuk menarik nasabah yang pada akhirnya nasabah mendapatkan keuntungan dari keadaan tersebut, karena itu dunia Bank BTN Kantor Cabang Padang tidak mempunyai banyak pilihan kecuali meningkatkan profesionalisme, kompetensi dan daya saing.

Undang-Undang Nomor 10 Tahun 1998 (Pasal 1) tentang perubahan UndangUndang Nomor 7 tahun 1992 tentang Perbankan menyebutkan bahwa bank adalah badan usaha yang menghimpun dana dari masyarakat dalam bentuk simpanan dan menyalurkannya kepada masyarakat dalam bentuk kredit dan atau bentuk lainnya dalam rangka meningkatkan taraf hidup rakyat banyak.

Dalam rangka intensifikasi penghimpun dana masyarakat, perlunya pemanfaatan sarana-sarana penghimpun dana dalam bentuk simpanan yang terdiri dari: Giro, Deposito, dan Tabungan. Dalam mengatasi persaingan, maka aktivitas pemasaran sangat penting. Karena akan mempengaruhi tingkat pertumbuhan dana pada perusahaan.

Bagaimanakah Aktivitas Pemasaran yang dilakukan PT. Bank Tabungan Negara (Persero) Tbk Kantor Cabang Padang dalam meningkatkan penghimpunan dana dalam bentuk simpanan.

Tujuan Penelitian

a. Untuk mengetahui bagaimana aktivitas pemasaran produk simpanan pada Bank BTN Kantor Cabang Padang.

b. Untuk mengembangkan pengetahuan yang telah di peroleh selama di AKBP Padang. 
Metode Pengumpulan data

Penelitian yang dilakukan dengan membaca beberapa buku-buku ilmiah dan tulisantulisan yang berkaitan dengan pembahasan yang dilakukan dan peninjauan langsung objek penelitian untuk meneliti hasil data primer.

\section{METODE ANALISIS DATA}

Dalam menganalisis data menggunakan analisis data kualititatif yang menjelaskan secara deskriptif mengenai Aktivitas Pemasaran Produk Simpanan PT Bank Tabungan Negara (Persero) Tbk Kantor Cabang Padang.

\section{LANDASAN TEORI}

\section{Pengertian Pemasaran}

a. American Marketing Association (AMA) dalam buku Kotler dan Keller tentang Manajemen Pemasaran, menawarkan definisi formal berikut : Pemasaran adalah suatu fungsi organisasi dan serangkaian proses untuk menciptakan, mengomunikasikan, dan memberikan nilai kepada pelanggan dan untuk mengelola hubungan pelanggan dengan cara yang menguntungkan organisasi dan pemangku kepentingannya.

b. Philip Kotler mengemukakan pengertian pemasaran adalah suatu proses sosial dengan mana individu dan kelompok mendapatkan apa yang mereka butuhkan dan inginkan dengan menciptakan dan mempertukarkan produk dan nilai dengan individu dan kelompok lainnya.

c. Staton mengemukakan pengertian pemasaran adalah sistem keseluruhan dari kegiatan usaha yang ditunjuk untuk merencanakan, menentukan harga, mempromosikan dan mendistribusikan barang serta jasa yang dapat memuaskan kebutuhan pembeli yang ada maupun pembeli yang potensial.

\section{Strategi Pemasaran}

Kotler menyebutkan konsep pemasaran produk terdiri dari 4P, yaitu :

a. Product (Produk),

b. Price (Harga),

c. Place (Tempat),

d. Promotion (Promosi).

Sedangkan Boom dan Bitner menambahkan 3P dalam konsep pemasaran bisnis jasa yaitu :

a. People (Orang),

b. Process (Proses),

c. Physical Evidence (Fasilitas Fisik).

Dari penjelasan diatas dapat disimpulkan bahwa keseluruhan penggunaan konsep pemasaran untuk produk dan jasa menjadi 7P.

\section{Pengertian Simpanan}

Undang-Undang Perbankan Nomor 10 Tahun 1998 pasal 1 butir (5), tentang perubahan atas Undang-Undang Perbankan Nomor 7 Tahun 1992 menyebutkan bahwa simpanan adalah dana yang dipercayakan masyarakat kepada bank berdasarkan perjanjian penyimpanan dana dalam bentuk giro, deposito, tabungan dan/atau bentuk lain yang dipersamakan dengan itu.

Macam-Macam Produk Simpanan pada Bank Konvensional :
a. Tabungan
b. Deposito
c. Giro 


\section{ANALISA DAN PEMBAHASAN}

\section{Pemasaran yang dilakukan oleh Bank BTN Cabang Padang}

\section{a. Product (Produk)}

Produk merupakan hal utama yang harus ada dalam pemasaran, adapun produk simpanan yang disediakan oleh Bank BTN Cabang Padang adalah :

\section{1) Tabungan}

Yaitu simpanan yang penarikannya hanya dapat dilakukan menurut syarat-syarat tertentu yang disepakati, tetapi tidak dapat ditarik dengan cek, bilyet giro dan/atau alat lainnya yang dipersamakan dengan itu.

Jenis-jenis tabungan pada Bank BTN Cabang Padang adalah :

a) Tabungan BTN Batara

Yaitu tabungan dengan berbagai kemudahan transaksi untuk menunjang aktivitas keungan nasabah.

b) Tabungan BTN Prima

Yaitu tabungan investasi dengan berbagai keuntungan untuk menjadikan kehidupan yang lebih baik lagi.

c) Tabungan BTN Payroll

Yaitu tabungan Batara yang khusus digunakan untuk nasabah yang memakai fasilitas Payroll Bank BTN (Perusahaan, perorangan, lembaga yang mana dalam mengelola pembayaran gaji, THR, dan bonus serta kebutuhan finansial lainnya yang bersifat rutin bagi karyawan penggunaan jasa).

d) Tabungan BTN Junior

Yaitu tabungan untuk edukasi menabung bagi Anak-anak usia sampai dengan 12 tahun.

e) Tabungan BTN Juara

Yaitu tabungan untuk edukasi dan sesuai dengan kebutuhan generasi muda usia 12 sampai dengan 23 tahun.

f) Tabungan e'Batarapos

Merupakan produk tabungan Bank BTN yang diselenggarakan bekerjasama dengan PT. Pos Indonesia (Persero) melalui loket kantor Pos yang telah ditentukan.

g) TabunganKu

Yaitu tabungan perorangan dengan persyaratan mudah \& ringan untuk menumbuhkan budaya menabung serta meningkatkan kesejahteraan masyarakat.

h) Tabungan BTN Haji - Reguler

Merupakan tabungan yang diperuntukkan kepada calon jamaah haji yang akan mempersiapkan ibadah haji dengan program penyelenggaraan haji reguler

i) Tabungan BTN Haji - Plus

Merupakan tabungan yang khusus diperuntukkan kepada calon jemaah haji yang akan menjalankan ibadah haji dengan program penyelenggaraan Haji Khusus yang diselengarakan oleh Kantor Kementriaan Agama.

j) Tabungan BTN Batara Pensiunan Merupakan tabungan yang diperuntukkan bagi para pensiunan sebagai sarana penerimaan pensiun setiap bulan yang dibayarkan oleh PT. Taspen (Persero).

k) Tabungan Simpanan Pelajar (SimPel)

Yaitu tabungan untuk siswa yang diterbitkan secara nasional oleh bank-bank di Indonesia, dengan persyaratan mudah dan sederhana serta fitur yang menarik, dalam rangka edukasi dan inklusi keuangan untuk mendorong budaya menabung sejak dini. 
1) Tabungan BTN Perumahan

Merupakan produk tabungan dalam rangka membantu lebih banyak masyarakat di Indonesia untuk menabung dengan tujuan membeli rumah, khususnya rumah pertama. Segmen yang dituju adalah Nasabah yang baru menikah dan orang-orang muda (mereka yang pertama mendapatkan pekerjaan dan level manager menengah) yang telah menyadari kebutuhan akan kepemilikan rumah.

\section{2) Deposito}

Yaitu simpanan pada bank yang penarikannya sesuai jangka waktu (jatuh tempo) dan dapat ditarik dengan bilyet deposito tau sertifikat deposito.

Jenis-jenis deposito pada Bank BTN Cabang Padang adalah :

a) Deposito BTN

Yaitu simpanan berjangka dalam mata uang rupiah dengan jangka waktu penempatan bervariasi mulai dari 1 bulan, 3 bulan, 6 bulan, 12 bulan, dan 24 bulan.

b) Deposito BTN Valas

Merupakan simpanan berjangka dalam mata uang USD dengan jangka waktu penempatan bervariasi mulai dari 1 bulan, 3 bulan, 6 bulan, 12 bulan, dan 24

3) Giro

bulan yang dapat dibuka di seluruh kantor cabang devisa.

Yaitu simpanan yang penarikannya dapat dilakukan setiap saat dengan menggunakan cek, bilyet giro, sarana pemerintah pembayaran lainnya atau dengan cara pemindahbukukan.

Jenis-jenis giro Bank BTN Cabang Padang adalah :

a) Giro BTN

Merupakan produk simpanan dengan fleksibilitas tinggi yang penarikannya dapat dilakukan setiap saat dengan menggunakan Cek/BG atau media lainya.

b) Giro Valas BTN

Merupakan produk simpanan dalam denominasi USD dengan fleksibilitas tinggi yang penarikannya dapat dilakukan setiap saat dengan menggunakan $\mathrm{Cek} / \mathrm{BG}$ atau media lainnya.

b. Place (Tempat)

1) Kantor BTN Cabang Padang yang berada di JL. HR. Rasuna Said No.3 Padang.

2) Kantor Cabang Pembantu Dr. Sutomo yang berada di Jl. Dr. Sutomo No. 37B Padang.

3) Kantor Cabang Pembantu Ulak Karang yang berada di Jl. S. Parman no.31 F Padang

4) Kantor Cabang Pembantu Pasar Raya Padang yang berada di Jl. M. Yamin No.130 Pasar Raya - Padang.

5) Kantor Cabang Pembantu Bukittinggi yang berada di Jl. Jendral Sudirman Bo. 75 Bukittinggi.

6) Kantor Kas Lubuk Buaya yang berada di Jl. Adinegoro No. 67 Lubuk Buaya, Padang.

7) Kantor Kas Siteba yang berada di Jl. Raya Siteba Padang.

8) Kantor Kas Bandar Buat yang berada di Jl. Raya Bandar Buat Indarung No. 28 Padang.

9) Kantor Pelayanan Pos Online yang berada didaerah Padang.

\section{c. Price (Harga)}

Demikian penetapan harga oleh pihak bank berhubungan dengan :

1) Bagaimana nasabah menerima harga produk yang ditawarkan oleh bank. 
2) Nilai subjektif dari kedua belah pihak (Bank dan nasabah).

Kebijakan penetapan tingkat bunga oleh Bank BTN Cabang Padang dilakukan dengan menetapkan tingkat bunga tabungan dan giro lebih rendah dari pada tingkat bunga deposito, hal ini dikarenakan oleh simpanan deposito lebih pasti (hanya dapat diandalkan pada saat jatuh tempo).

\section{d. Promotion (Promosi)}

Promosi merupakan sarana yang paling tepat untuk menarik dan mempertahankan nasabah. Salah satu tujuan promosi bank adalah menginformasikan segala jenis produk yang ditawarkan dan berusaha menarik calon nasabah yang baru. Adapun bentuk promosi yang telah dilakukan oleh Pihak PT. BTN Cabang Padang dalam usaha memperkenalkan produk kepada masyarakat adalah :

\section{1) Periklanan}

Periklanan yang telah dilakukan oleh BTN Cabang Padang adalah dengan menayangkan iklanya melalui surat kabar Padang Expres, Singgalang, radio RRI, pemasangan papan-papan reklame dan spanduk serta pemberian brosur-brosur kepada masyarakat.

\section{2) Promosi Penjualan}

Promosi penjualan langsung dilaksanakan oleh BTN Cabang Padang kepada masyarakat sehingga masyarakat merasa tetarik untuk menabung di bank BTN. Misalnya dengan memberikan pelayanan yang ramah kepada nasabah atau memberikan sumbangan-sumbangan atas kegiatan yang dikoordinir oleh Pemerintah Daerah.

3) Publisitas

Kegiatan publisitas dimaksudkan untuk menjaga hubungan baik dengan seluruh masyarakat yang berada dalam wilayah operasional bank. Kegiatan yang telah dilakukan antara lain ikut berpartisipasi dalam kegiatan sosial dan kemasyarakatan seperti menggalakan program K.3, memberikan sumbangan-sumbangan dan kegiatan sosial lainya serta memberikan keterangan-keterangan di media masa tentang gambaran umum PT. BTN Cabang Padang sekarang dan dimasa yang akan datang.

\section{4) Penjualan Pribadi}

Penjualan Pribadi ini secara khusus dilaksanakan oleh petugas yang disebut Customer Service (CS). Karyawan bank dari satpam sampai pimpinan bank harus mampu menjelaskan segala sesuatunya tentang produk dan yang lainya bila diperlukan oleh nasabah. Bank juga menugaskan karyawan secara langsung untuk mendatangi calon-calon nasabah potensial dan memberikan keterangan yang diperlukan untuk penghimpunan dana dan pemberian kredit.

\section{e. People (Orang)}

Etika Perorangan Pegawai Bank BTN Cabang Padang adalah sebagai berikut :

1) Patuh dan taat pada ketentuan perundang-undangan dan peraturan yang berlaku.

2) Melakukan pencatatan yang benar mengenai segala transaksi yang bertalian dengan kegiatan bank BTN.

3) Menghindarkan diri dari persaingan yang tidak sehat.

4) Tidak menyalahgunakan wewenangnya untuk kegiatan pribadi.

5) Menghindarkan diri dari keterlibatan dalam pengambilan keputusan dalam hal terdapat pertentangan kepentingan.

6) Menjaga kerahasiaan nasabah dan bank BTN.

7) Memperhitungkan dampak yang merugikan dari setiap kebijakan yang ditetapkan bank BTN terhadap keadaan ekonomi, sosial dan lingkungannya. 
8) Tidak menerima hadiah atau imbalan yang memperkaya diri pribadi maupun keluarganya.

9) Tidak melakukan perbuatan tercela yang dapat merugikan citra profesinya.

\section{f. Process (Alur Kerja)}

Proses merupakan gabungan semua aktivitas, umumnya terdiri dari prosedur, jadwal kerja, mekanisme, aktivitas produk dan jasa bank yang disampaikan kepada nasabah, prosedur pelaksanaan, mekanisme kerja. Alur pelayanan nasabah dan hal-hal lain yang bersifat rutin.

\section{g. Physical Eviden (Bukti Fisik)}

Untuk meningkatkan pelayanan pada masyarakat atau nasabah, maka Bank BTN Cabang Padang melakukan hal-hal sebagai berikut :

1) Menyediakan tempat atau kantor dan ruang tunggu yang luas dan nyaman sehingga nasabah merasa nyaman bila memasuki kantor BTN.

2) Tata ruang kerja karyawan yang sangat mendukung sehingga dapat meningkatkan semangat karyawan bekerja.

3) Melakukan penghimpunan dana langsung ke tempat nasabah yang dilakukan oleh karyawan bagian pemasaran sebagai petugas lapangan. Dengan adanya petugas yang langsung melakukan penghimpunan dana ke lokasi nasabah tidak perlu lagi datang ke bank untuk melakukan penyetoran dan penarikan karena bisa dilakukan melalui petugas lapangan.

4) Melakukan penagihan langsung ke lokasi nasabah, sehingga memudahkan nasabah melakukan penyetoran pembayaran angsuran kredit.

5) Tersedia komputer yang dapat memudahkan dan mempercepat kegiatan operasional bank seperti menyimpan data-data masyarakat, angsuran kredit, dan mempermudah dalam pembuatan surat menyurat.

6) Adanya satpam yang dapat memberikan kondisi aman di bank.

Tujuh konsep pemasaran yang dilakukan oleh Bank BTN Cabang Padang diatas merupakan strategi bauran pemasaran (Marketing Mix).

\section{Perkembangan Dana Produk Simpanan Pada PT. Bank Tabungan Negara (Persero)} Tbk. Kantor Cabang PadangTahun 2012 - 2016 dalam Miliyar Rupiah

\begin{tabular}{|l|l|l|l|l|l|l|l|l|}
\hline \multirow{2}{*}{ Tahun } & \multicolumn{2}{|c|}{ Tabungan } & \multicolumn{2}{c|}{ Deposito } & \multicolumn{2}{c|}{ Giro } & \multicolumn{2}{c|}{ Produk Simpanan } \\
\cline { 2 - 9 } & Jumlah & $\begin{array}{c}\text { Perubaha } \\
\mathbf{n}(\boldsymbol{\%})\end{array}$ & Jumlah & $\begin{array}{c}\text { Perubaha } \\
\mathbf{n}(\boldsymbol{\%})\end{array}$ & Jumlah & $\begin{array}{c}\text { Perubaha } \\
\mathbf{n}(\boldsymbol{\%})\end{array}$ & Jumlah & $\begin{array}{c}\text { Perubahan } \\
(\%)\end{array}$ \\
\hline 2012 & 185,656 & & 91,053 & & 82,098 & & 358,807 & \\
\hline 2013 & 202,972 & 9.33 & 153,597 & 68.69 & 119,949 & 46.11 & 476,512 & 32.78 \\
\hline 2014 & 220,751 & 8.76 & 135,801 & 11.59 & 112,883 & 5.90 & 469,435 & 1.49 \\
\hline 2015 & 318,240 & 44.16 & 238,300 & 75.48 & 126,518 & 12.08 & 683,058 & 45.51 \\
\hline 2016 & 356,578 & 12.05 & 522,561 & 119.29 & 125,190 & 1.05 & $1,004,329$ & 47.03 \\
\hline Total & $1,284,197$ & & $1,141,312$ & & 566,638 & & $2,992,141$ & \\
\hline
\end{tabular}

Dari tabel di atas dapat diketahui bahwa perkembangan dana pada produk simpanan. Baik produk tabungan, deposito, dan giro mengalami peningkatan dan juga penurunan posisi dana dari tahun ke tahun. Untuk produk tabungan pada tahun 2012 berjumlah Rp. 196.108 Miliyar, pada tahun 2013 berjumlah Rp. 202.972 Miliyar, mengalami peningkatan sebesar Rp. 6.864 Miliyar atau naik 9,33\% dari tahun 2012. Pada tahun 2014 berjumlah Rp. 220.751 Miliyar, mengalami peningkatan sebesar Rp. 17.779 Miliyar atau naik 8,76\% dari tahun 2013. Tahun 2015 berjumlah Rp. 318.240 Miliyar, mengalami peningkatan sebesar Rp. 97.489 Miliyar atau naik 44,16\% dari tahun 2014. Pada tahun 2016 berjumlah Rp. 356.578 Miliyar, mengalami peningkatan sebesar Rp. 38.338 atau naik $12,05 \%$ dari tahun 2015. 
Untuk produk deposito, pada tahun 2012 berjumlah Rp. 91.053 Miliyar, pada tahun 2013 berjumlah Rp. 153.597 Miliyar, mengalami peningkatan sebesar Rp. 62.544 Miliyar atau naik 68.69\% dari tahun 2012. Pada tahun 2014 berjumlah Rp. 135.801 Miliyar, mengalami penurunan sebesar Rp. 17.796 Miliyar atau turun 11,59\% dari tahun 2013 yang disebabkan oleh kurangnya kegiatan promosi yang dilakukan oleh pihak bank. Pada tahun 2015 berjumlah Rp. 238.300 Miliyar, mengalami peningkatan sebesar Rp. 102.499 Miliyar atau naik 75,48\% dari tahun 2014. Pada tahun 2016 berjumlah Rp. 522,561 Miliyar, mengalami peningkatan yang dratis sebesar Rp. 284.261 Miliyar atau naik 119,29\% dari tahun 2015.

Untuk produk Giro, pada tahun 2012 berjumlah Rp. 82.098 Miliyar, pada tahun 2013 berjumlah Rp. 119.949 Miliyar, mengalami peningkatan sebesar Rp. 37.851 Miliyar atau naik 46,11\% dari tahun 2012. Pada tahun 2014 berjumlah Rp. 112.883 Miliyar, mengalami penurunan sebesar Rp. 7.066 atau turun 5,90\% dari tahun 2013 yang disebabkan oleh kurangnya kegiatan promosi yang dilakukan oleh pihak bank. Pada tahun 2015 berjumlah Rp. 126.190 Miliyar, mengalami peningkatan kembali sebesar Rp. 13.635 Miliyar atau naik 12,08\% dari tahun 2014. Pada tahun 2016 berjumlah Rp. 125.190 Miliyar, mengalami penurunan kembali sebesar Rp. 1.328 Miliyar atau turun 1,05\% dari tahun 2015.

Dari ketiga jenis tersebut, dapat diketahui perkembangan total dana produk simpanan masyarakat yaitu pada tahun 2012 berjumlah Rp.358.807 Miliyar, pada tahun 2013 berjumlah Rp. 476,512, mengalami kenaikan sebesar Rp. 117.705 Miliyar atau naik 32.78\% dari tahun 2012. Pada tahun 2014 berjumlah Rp. 469.435 Miliyar, mengalami penurunan sebesar Rp. 7.077 Miliyar atau turun 1,49\% dari tahun 2013, penurunan tersebut disebabkan oleh kurangnya kegiatan promosi yang dilakukan oleh pihak bank kepada masyarakat. Pada tahun 2015 berjumlah Rp. 683.058 Miliyar, mengalami peningkatan sebesar Rp. 213.623 Miliyar atau naik 45,51\% dari tahun 2014. Pada tahun 2016 berjumlah Rp. 1.004.329 Miliyar, mengalami peningkatan sebesar Rp. 321.271 atau naik 47,03\% dari tahun 2015.

\section{Permasalahan yang Dihadapi dan Usaha untuk Mengatasinya}

Kendala yang dihadapi oleh Bank BTN Cabang Padang dalam memasarkan produk simpanan adalah masyarakat belum mengenal tentang produk-produk yang ada pada perbankan, jadi pihak perbankan kesulitan dalam memasarkan produk simpanan kepada masyarakat karena pesan yang ingin disampaikan oleh pihak perbankan tidak sampai kepada masyarakat.

Usaha yang dilakukan oleh pihak perbankan untuk mengatasi masalah yang sedang dihadapi adalah dengan melakukan pendekatan-pendekatan kepada nasabah seperti dilakukan nya sosialisasi, pameran-pameran, dan berpartisipasi dalam kegiatan sosial dan kemasyarakatan.

Maka masyarakat akan mulai mengenal tentang produk yang sedang dipasarkan oleh pihak perbankan dan melakukan kerja sama dalam melakukan penyimpanan pada Bank BTN Cabang Padang.

\section{PENUTUP}

\section{Kesimpulan}

a. PT. Bank Tabungan Negara (Persero) Tbk. Kantor Cabang Padang melakukan aktivitas pemasaran produk simpanan menggunakan strategi bauran pemasaran atau Marketing Mix yang terdiri dari konsep 7P yaitu : Product (Produk), Price (Harga), Place (Tempat), dan Promotion (Promosi), People (Orang), Process (Proses), dan Physical Evidence (Fasilitas Fisik). 
b. Dalam melakukan aktivitas pemasarannya, PT. Bank Tabungann Negara (Persero) Tbk. Kantor Cabang Padang berhasil menerapkan kebijakan bauran pemasaran dengan baik, ini terlihat dari jumlah penghimpunan dana simpanan dari tahun ke tahun, khususnya dalam lima tahun terakhir selalu meningkat.

\section{Saran}

a. Dalam penetapan kebijakan tingkat suku bunga hendaknya bank bisa memberikan bunga yang lebih tinggi dibanding dengan bank lain sehingga nasabah akan lebih tertarik lagi menyimpan uangnya.

b. Hendaknya kegiatan promosi berupa kegiatan sosialisasi, undian, dan pameran dapat berlanjut sehingga nasabah lebih bersemangat dalam menyimpan uangnya di bank serta hendaknya bank memberikan fasilitas pelayanan yang lebih baik lagi sehingga nasabah yang sudah ada akan merasakan kepuasan dari pelayanan yang diberikan oleh pihak bank.

\section{DAFTAR PUSTAKA}

Andika, A., \& Susanti, F. (2018). Pengaruh Marketing Mix Terhadap Keputusan Pembelian Parfum di Azzwars Parfum Lubeg Padang. https://doi.org/10.31227/osf.io/upgc3

Dendawijaya, Lukman. (2001). Manajemen Perbankan. Jakarta: Ghalia Indonesia.

Diulio. (1993). Uang dan Bank. Jakarta: Erlangga.

Hidayati, R. R., \& Marlius, D. (2018). Aktivitas Promosi Dalam Meningkatkan Dana Pihak Ketiga Pada PT. Bank Perkreditan Rakyat (BPR) Batang Kapas Pesisir Selatan. https://doi.org/10.31227/osf.io/8dgqn

Kasmir. (2008). Pemasaran Bank. Jakarta: Kencana.

Kotler dan Keller. (2008). Manajemen Pamasaran. Erlangga: Jakarta.

Kotler, Philip. (1994). Manajemen Pemasaran, Analisis, Perencanaan, Pengendalian. Jakarta: Erlangga.

Latumaerissa, Julius R. (2012). Bank dan Lembaga Keuangan Lain. Jakarta: Salemba Empat.

Marlius, D. (2017). Keputusan Pembelian Berdasarkan Faktor Psikologis Dan Bauran Pemasaran Pada PT. Intercom Mobilindo Padang. Jurnal Pundi. Volume 1. No. 1. Hal. 57-66. https://doi.org/10.31575/jp.v1i1.9

Marlius, D. (2016). Pengaruh Bauran Pemasaran Jasa Terhadap Minat Nasabah Dalam Menabung Pada Bank Nagari Cabang Muaralabuh. https://doi.org/10.31227/osf.io/vdqgx

Stanton, J, William, (1995), Azas-Azas Marketing, Yogyakarta, BFE UGM.

Susanti, F. (2015). Pengaruh Bauran Promosi Terhadap Keputusan Klien Dalam Memilih Radio Carano Sebagai Media Promosi Iklan. https://doi.org/10.31227/osf.io/b9ws7 
Susanti, F., \& Gunawan, A. C. (2019). Pengaruh Bauran Promosi Dan Harga Terhadap Keputusan Pembelian Produk Kosmetik Maybelline Di Kota Padang. https://doi.org/10.31227/osf.io/npjqh

Undang-Undang Nomor 10 Tahun 1998, Tentang Perubahan Undang-Undang Nomor 7 Tahun 1992 Tentang Perbankan. 